\title{
Alkyl chain-functionalized hole-transporting domains in zinc(II) dye-sensitized solar cells
}

\author{
Nik Hostettler, Sebastian O. Fürer, Biljana Bozic-Weber, Edwin C. Constable* and \\ Catherine E. Housecroft* \\ Department of Chemistry, University of Basel, Spitalstrasse 51, 4056-Basel, Switzerland \\ Fax: +41 61267 1018; E-mail: catherine.housecroft@unibas.ch
}

\begin{abstract}
FTO/ $\mathrm{TiO}_{2}$ electrodes have been functionalized with $\left\{\mathrm{Zn}\left(\mathrm{tpy}_{\text {anchor }}\right)\left(\mathrm{tpy}_{\text {ancillary }}\right)\right\}^{2+}$ dyes (tpy $=2,2^{\prime}: 6^{\prime}, 2^{\prime \prime}$-terpyridine) using a stepwise method to sequentially introduce (i) the anchoring ligand tpy anchor (either a dicarboxylic acid or a diphosphonic acid), (ii) $\mathrm{Zn}^{2+}$ ions, and (iii) chromophoric ancillary (4-([2,2':6',2"-terpyridin]-4'-yl)- $N, N$-bis(4alkoxyphenyl)aniline ligands. A comparison of unmasked and fully masked DSSCs containing representative dyes shows a significant drop in photon-to-current efficiency upon masking. Solid-state absorption spectra of the dye-functionalized electrodes confirm that the intensity of absorption decreases with the steric demands of the ancillary ligand. DSSC measurements show that the $\left\{\mathrm{Zn}\left(\mathrm{tpy}_{\text {anchor }}\right)\left(\text { tpy }_{\text {ancillary }}\right)\right\}^{2+}$ dyes give poor photon-tocurrent efficiencies, values of the short circuit current density $\left(J_{\mathrm{SC}}\right)$ and the external quantum efficiency (EQE) spectra are consistent with very poor electron injection. Introducing longer alkoxy chains in place of methoxy substituents in the hole-

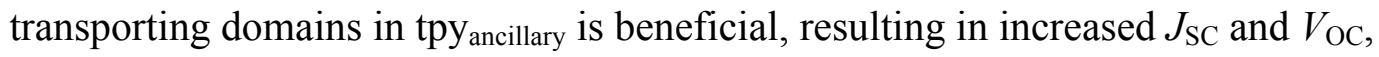
although values remain low despite the 'push-pull' design of the sensitizers.
\end{abstract}

Keywords: zinc; sensitizer; DSSC; surface-functionalization; 'surfaces-as-ligands' 


\section{Introduction}

Organic compounds [1] and d-block metal complexes [2] are both used as coloured compounds in dye-sensitized solar cells (DSSCs). Among metal-containing dyes, ruthenium(II) complexes are the most widely explored [3], but there is increasing interest in sensitizers based on Earth abundant metals [4]. Bis(diimine)copper(I) dyes were first evaluated in DSSCs by Sauvage and coworkers [5] and, generations of dyes later, a record photoconversion efficiency of $4.66 \%$ has been reported with a heteroleptic copper(I) complex assembled using the HETPHEN approach [6]. Heteroleptic $\left[\mathrm{Cu}(\mathrm{L})\left(\mathrm{L}^{\prime}\right)\right]^{+}$species usually equilibrate in solution to give a mixture of homo- and heteroleptic complexes. The HETPHEN strategy [7] minimizes ligand dissociation by using bulky substituents [6,8]. In contrast, we have developed a 'surfaces-as-ligands' [9] methodology in which the $\mathrm{TiO}_{2}$ surface is first functionalized with an anchoring ligand, $\mathrm{L}_{\text {anchor, }}$, to give an active domain that can either undergo ligand exchange with a homoleptic $\left[\mathrm{Cu}\left(\mathrm{L}_{\text {ancillary }}\right)_{2}\right]^{+}$complex [10] or be treated with $\left[\mathrm{Cu}(\mathrm{MeCN})_{4}\right]\left[\mathrm{PF}_{6}\right]$ followed by an ancillary ligand [11]. Compared to the former method where an equivalent of $\mathrm{L}_{\text {ancillary }}$ is wasted, the latter is atom-efficient (Scheme 1) and was developed using $2,2^{\prime}: 6^{\prime}, 2^{\prime \prime}$-terpyridine (tpy) ligands for the assembly of dyes containing $\left\{\mathrm{Zn}(\operatorname{tpy})_{2}\right\}^{2+}$ domains (Scheme 1) [12].

With the exception of zinc(II) porphyrin dyes [13,14], little effort has been made to optimize zinc(II) sensitizers for DSSCs. An advantage of developing $\left\{\mathrm{Zn}\left(\mathrm{tpy}_{\text {anchor }}\right)\left(\text { tpy }_{\text {ancillary }}\right)\right\}^{2+}$ dyes is that it allows a library of light-harvesting ligand domains to be combined through facile coordination to zinc(II) (Scheme 1). In zinc(II) complexes, the visible region photoresponse is determined by the ligands, making these dyes distinct from those containing the $\mathrm{d}^{10} \mathrm{Cu}^{+}$ion which exhibit metal-to-ligand charge 
transfer (MLCT) bands. Our initial trials of $\left\{\mathrm{Zn}\left(\mathrm{tpy}_{\text {anchor }}\right)\left(\operatorname{tpy}_{\text {ancillary }}\right)\right\}^{2+}$ dyes used $\mathbf{1}$ or $\mathbf{2}$ (Scheme 2) as the ancillary ligand. Ligands $\mathbf{1}$ and $\mathbf{2}$ are chromophoric by virtue of an intra-ligand charge transfer (ILCT) band with the tertiary amine acting as an electron donor [15], and photoconversion efficiencies of up to $0.71 \%$ (relative to $7.29 \%$ for N719) were achieved for unmasked DSSCs containing $\mathrm{TiO}_{2}$-supported $[\mathrm{Zn}(\mathbf{1})(\mathbf{3})]^{2+}$ dyes. We have now extended these studies using masked DSSCs (which prevents overestimation of cell performance [16]) and have introduced alkyl chains onto the periphery of the holetransporting domains in an attempt to reduce charge recombination events detrimental to DSSC performance $[17,18,19,20,21]$.

$<$ Scheme 1 here $>$

$<$ Scheme 2 here $>$

\section{Experimental}

\section{$2.1 \quad$ General}

${ }^{1} \mathrm{H}$ and ${ }^{13} \mathrm{C}$ NMR spectra were recorded on a Bruker Avance III-500 or $400 \mathrm{MHz}$ NMR spectrometer; chemical shifts were referenced to residual solvent peaks with respect to $\partial(\mathrm{TMS})=0 \mathrm{ppm}$. Solution absorption spectra were recorded using a Cary 5000 or Agilent 8453 spectrophotometer, and FT-IR spectra using a Perkin Elmer Spectrum Two with UATR for solid samples. MALDI-TOF, electrospray ionization (ESI) mass spectra were recorded on Bruker esquire $3000^{\text {plu }}$ and Bruker Daltonics Inc. microflex instruments, respectively; LC-ESI-MS mass spectra used a combination of Shimadzu (LC) and Bruker AmaZon X instruments. 
Compound 3 [12] and 4'-(4-bromophenyl)-2,2':6',2"-terpyridine [22] were prepared as previously reported; 4,4'-di-n-butoxydiphenylamine, 4-isobutoxyaniline, 1bromo-4-n-octoxybenzene and 4-n-octoxyaniline were prepared by the method reported for the analogous hexoxy compounds [23] and spectroscopic data compared to those reported $[24,25,26,27]$. Bis(dibenzylideneacetone)palladium(0), $\left[\mathrm{Pd}(\mathrm{dba})_{2}\right]$ was purchased from Strem Chemicals. The dye N719 was purchased from Solaronix.

\subsection{1-Bromo-4-isobutoxybenzene}

1-Bromo-4-isobutoxybenzene was prepared by the method reported for the analogous hexoxy compound [23]. 4-Bromophenol (5.00 g, $28.9 \mathrm{mmol})$ was dissolved in acetone (60 mL). After the addition of $\mathrm{K}_{2} \mathrm{CO}_{3}(7.99 \mathrm{~g}, 57.8 \mathrm{mmol})$, the white suspension was stirred for $5 \mathrm{~min}$, then 1-bromo-2-methylpropane $(4.76 \mathrm{~mL}, 43.4 \mathrm{mmol})$ was added and the mixture heated at reflux for $3 \mathrm{~d}$. After the mixture was cooled to room temperature, it was filtered and the filtrate concentrated in vacuo to give a colourless oil. This was dissolved in $\mathrm{CH}_{2} \mathrm{Cl}_{2}$, washed with aqueous $\mathrm{NaOH}(3 \times 50 \mathrm{~mL}, 2.0 \mathrm{M})$ and water $(2 \times 50$ $\mathrm{mL}$ ), then dried over $\mathrm{MgSO}_{4}$. After filtration, the filtrate was concentrated under reduced pressure to yield 1-bromo-4-isobutoxybenzene as a light yellow oil (1.78 g, $7.75 \mathrm{mmol}$, 26.8\%) ${ }^{1} \mathrm{H}$ NMR $\left(500 \mathrm{MHz}, \mathrm{CDCl}_{3}\right) \delta / \mathrm{ppm} 7.36\left(\mathrm{~d}, J=9.1 \mathrm{~Hz}, 2 \mathrm{H}, \mathrm{H}^{\mathrm{Ar} 2}\right), 6.77(\mathrm{~d}, J=$ $\left.9.0 \mathrm{~Hz}, 2 \mathrm{H}, \mathrm{H}^{\mathrm{Ar} 3}\right), 3.68\left(\mathrm{~d}, J=6.6 \mathrm{~Hz}, 2 \mathrm{H}, \mathrm{H}^{\mathrm{OCH} 2}\right), 2.07\left(\mathrm{~m}, 1 \mathrm{H}, \mathrm{H}^{\mathrm{CH}}\right), 1.01(\mathrm{~d}, J=6.7$ $\left.\mathrm{Hz}, 6 \mathrm{H}, \mathrm{H}^{\mathrm{Me}}\right)$.

\subsection{4,4'-Di-isobutoxydiphenylamine}

A round-bottomed flask was charged with $\mathrm{K}_{2} \mathrm{CO}_{3}(1.21 \mathrm{~g}, 8.73 \mathrm{mmol}), \mathrm{CuI}(83.1 \mathrm{mg}$, $0.436 \mathrm{mmol}$ ) and L-proline (100 $\mathrm{mg}, 0.873 \mathrm{mmol})$ under an $\mathrm{N}_{2}$ atmosphere and then DMSO $(20 \mathrm{~mL})$ was added. The mixture was stirred until most of the solid had dissolved. 
Then 1-bromo-4-isobutoxybenzene $(1.50 \mathrm{~g}, 6.55 \mathrm{mmol})$ and 4-isobutoxyaniline $(721 \mathrm{mg}$, $4.36 \mathrm{mmol}$ ) were added and the mixture heated at $90{ }^{\circ} \mathrm{C}$ for $3 \mathrm{~d}$. After cooling, water was added and extracted with EtOAc $(3 \times 25 \mathrm{~mL})$. The combined organic phases were washed with brine and dried over $\mathrm{MgSO}_{4}$. The solvent was removed under reduced pressure and the brown oil obtained was purified by column chromatography $\left(\mathrm{SiO}_{2}\right.$, hexane : EtOAc 10:1 changing to $10: 2$ then $10: 3$ then $0: 1$ ). 4,4'-Di-isobutoxydiphenylamine was obtained as a brown oil and was used without further purification (103 mg, $329 \mathrm{mmol}, 7.6 \%$ ). ${ }^{1} \mathrm{H}$ NMR $\left(500 \mathrm{MHz} \mathrm{CDCl}_{3}\right) \delta / \operatorname{ppm} 6.92\left(\mathrm{~d}, J=8.0 \mathrm{~Hz}, 4 \mathrm{H}, \mathrm{H}^{\mathrm{D} 2}\right), 6.81(\mathrm{~d}, J=8.9 \mathrm{~Hz}, 4 \mathrm{H}$, $\left.\mathrm{H}^{\mathrm{D} 3}\right), 3.68\left(\mathrm{~d}, J=6.7 \mathrm{~Hz}, 4 \mathrm{H}, \mathrm{H}^{\mathrm{CH} 2}\right), 2.05\left(\mathrm{~m}, 2 \mathrm{H}, \mathrm{H}^{\mathrm{CH}}\right), 1.02\left(\mathrm{~d}, J=6.7 \mathrm{~Hz}, 12 \mathrm{H}, \mathrm{H}^{\mathrm{Me}}\right)$. MALDI-TOF MS (m/z): $313.0[\mathrm{M}]^{+}$(calc. 313.2).

\subsection{4,4'-Di-n-octoxydiphenylamine}

The method was as for 4,4'-di-isobutoxydiphenylamine starting with 4-(octyloxy)aniline (1.50 g, $6.78 \mathrm{mmol}), \mathrm{K}_{2} \mathrm{CO}_{3}(1.87 \mathrm{~g}, 13.6 \mathrm{mmol}), \mathrm{CuI}(129 \mathrm{mg}, 0.678 \mathrm{mmol})$, L-proline (156 mg, $1.36 \mathrm{mmol}$ ) and 1-bromo-4-(octyloxy)benzene (2.90 g, $10.2 \mathrm{mmol})$. The reaction time was $4 \mathrm{~d}$. The product was purified by column chromatography $\left(\mathrm{SiO}_{2}\right.$, hexane : EtOAc 1:0 changing to $20: 1$ to $10: 1$ to $10: 2$ to $0: 1$ ) and was recrystallized twice from hexane. 4,4'-Di-n-octoxydiphenylamine was isolated as a white solid (320 mg, 0.752 mmol, 11.1\%). ${ }^{1} \mathrm{H}$ NMR (400 MHz, $\left.\mathrm{CDCl}_{3}\right) \delta / \mathrm{ppm} 6.92\left(\mathrm{~d}, J=8.9 \mathrm{~Hz}, 4 \mathrm{H}, \mathrm{H}^{\mathrm{D} 2}\right)$, $6.81\left(\mathrm{~d}, J=8.9 \mathrm{~Hz}, 4 \mathrm{H}, \mathrm{H}^{\mathrm{D} 3}\right), 3.91\left(\mathrm{t}, J=6.6 \mathrm{~Hz}, 4 \mathrm{H}, \mathrm{H}^{\mathrm{OCH} 2}\right), 1.75\left(\mathrm{~m}, 4 \mathrm{H}, \mathrm{H}^{\mathrm{OCH} 2 \mathrm{CH} 2}\right)$, $1.45\left(\mathrm{~m}, 4 \mathrm{H}, \mathrm{H}^{\mathrm{OCH}_{2} \mathrm{CH}_{2} \mathrm{CH}_{2}}\right), 1.39-1.23\left(\mathrm{~m}, 16 \mathrm{H}, \mathrm{H}^{\mathrm{CH}}\right), 0.88\left(\mathrm{t}, J=6.9 \mathrm{~Hz}, 6 \mathrm{H}, \mathrm{H}^{\mathrm{Me}}\right) . \mathrm{LC}-$ ESI: $m / z 426.4[\mathrm{M}+\mathrm{H}]^{+}$(calc. 426.3$)$.

\subsection{4-([2,2':6',2"'-Terpyridin]-4'-yl)-N,N-bis(4-n-butoxyphenyl)aniline (5)}


Solid 4'-(4-bromophenyl)-2,2':6',2"-terpyridine (500 mg, $1.29 \mathrm{mmol})$, bis(4- $n$ butoxyphenyl)amine (404 mg, $1.29 \mathrm{mmol})$ and $\mathrm{NaO}^{t} \mathrm{Bu}(161 \mathrm{mg}, 1.67 \mathrm{mmol})$ were placed in a flask under an $\mathrm{N}_{2}$ atmosphere. Toluene $(20 \mathrm{~mL})$ was added and the mixture was stirred vigorously for $5 \mathrm{~min}$. After the addition of $\left[\mathrm{Pd}(\mathrm{dba})_{2}\right](14.8 \mathrm{mg}, 25.8 \mu \mathrm{mol})$ and $\mathrm{P}^{t} \mathrm{Bu}_{3}(26 \mu \mathrm{L}, 25.8 \mu \mathrm{mol})$, the mixture was heated at $100{ }^{\circ} \mathrm{C}$ for $20 \mathrm{~h}$. The hot mixture was filtered into a hot Erlenmeyer flask to give a reddish filtrate. The solvent was removed under reduced pressure and the solid residue was recrystallized from EtOH and then subjected to column chromatography (basic $\mathrm{Al}_{2} \mathrm{O}_{3}$, hexane:EtOAc 10:1). Compound 5 was isolated as a pale yellow solid (152 mg, $0.245 \mathrm{mmol}, 19.0 \%)$. M. p. $122.9{ }^{\circ} \mathrm{C} .{ }^{1} \mathrm{H}$ NMR $\left(500 \mathrm{MHz} \mathrm{CDCl}_{3}\right) \delta / \operatorname{ppm} 8.72\left(\mathrm{ddd}, J=4.8,1.9,1.0 \mathrm{~Hz}, 2 \mathrm{H}, \mathrm{H}^{\mathrm{A} 6}\right), 8.68(\mathrm{~s}, 2 \mathrm{H}$, $\left.\mathrm{H}^{\mathrm{B} 3}\right), 8.65\left(\mathrm{~m}, 2 \mathrm{H}, \mathrm{H}^{\mathrm{A} 3}\right), 7.86\left(\mathrm{~m}, 2 \mathrm{H}, \mathrm{H}^{\mathrm{A} 4}\right), 7.74\left(\mathrm{~d}, J=8.8 \mathrm{~Hz}, 2 \mathrm{H}, \mathrm{H}^{\mathrm{C} 2}\right), 7.34(\mathrm{~m}, 2 \mathrm{H}$, $\left.\mathrm{H}^{\mathrm{A} 5}\right), 7.10\left(\mathrm{~d}, J=8.9 \mathrm{~Hz}, 4 \mathrm{H}, \mathrm{H}^{\mathrm{D} 2}\right), 7.01\left(\mathrm{~d}, J=8.8 \mathrm{~Hz}, 2 \mathrm{H}, \mathrm{H}^{\mathrm{C} 3}\right), 6.85(\mathrm{~d}, J=9.0 \mathrm{~Hz}, 4 \mathrm{H}$, $\left.\mathrm{H}^{\mathrm{D} 3}\right), 3.96\left(\mathrm{t}, J=6.5 \mathrm{~Hz}, 4 \mathrm{H}, \mathrm{H}^{\mathrm{OCH} 2}\right), 1.78\left(\mathrm{~m}, 4 \mathrm{H}, \mathrm{H}^{\mathrm{OCH}_{2} \mathrm{CH}_{2}}\right), 1.51\left(\mathrm{~m}, 4 \mathrm{H}, \mathrm{H}^{\mathrm{OCH}_{2} \mathrm{CH}_{2} \mathrm{CH}_{2}}\right)$, $0.99\left(\mathrm{t}, J=7.4 \mathrm{~Hz}, 6 \mathrm{H}, \mathrm{H}^{\mathrm{Me}}\right) .{ }^{13} \mathrm{C} \mathrm{NMR}\left(126 \mathrm{MHz}, \mathrm{CDCl}_{3}\right) \delta / \mathrm{ppm} 156.6\left(\mathrm{C}^{\mathrm{A} 2}\right), 155.9$ $\left(\mathrm{C}^{\mathrm{D} 4 / \mathrm{B} 2}\right), 155.85\left(\mathrm{C}^{\mathrm{D} 4 / \mathrm{B} 2}\right), 150.0\left(\mathrm{C}^{\mathrm{C} 4}\right), 149.9\left(\mathrm{C}^{\mathrm{C} 1}\right), 149.2\left(\mathrm{C}^{\mathrm{A} 6}\right), 140.4\left(\mathrm{C}^{\mathrm{D} 1}\right), 137.0\left(\mathrm{C}^{\mathrm{A} 4}\right)$, 129.6 $\left(\mathrm{C}^{\mathrm{B} 4}\right), 128.0\left(\mathrm{C}^{\mathrm{C} 2}\right), 127.1\left(\mathrm{C}^{\mathrm{D} 2}\right), 123.8\left(\mathrm{C}^{\mathrm{A} 5}\right), 121.5\left(\mathrm{C}^{\mathrm{A} 3}\right), 120.0\left(\mathrm{C}^{\mathrm{C} 3}\right), 118.1\left(\mathrm{C}^{\mathrm{B} 3}\right)$, $115.5\left(\mathrm{C}^{\mathrm{D} 3}\right), 68.1\left(\mathrm{C}^{\mathrm{OCH}_{2}}\right), 31.6\left(\mathrm{C}^{\mathrm{OCH}_{2} \mathrm{CH}_{2}}\right), 19.4\left(\mathrm{C}^{\mathrm{OCH}_{2} \mathrm{CH}_{2} \mathrm{CH}_{2}}\right), 14.0\left(\mathrm{C}^{\mathrm{Me}}\right) . \mathrm{IR}$ (solid, $\mathrm{cm}^{-}$ 1) $2951(\mathrm{w}), 2927(\mathrm{w}), 2869(\mathrm{w}), 1598(\mathrm{~m}), 1582(\mathrm{~s}), 1505(\mathrm{vs}), 1465(\mathrm{~s}), 1391(\mathrm{~m}), 1335$ (m), 1241 (vs), 1202 (s), 971 (m), 823 (vs), 790 (vs), 732 (s), 660 (m), 546 (s), 515 (m).

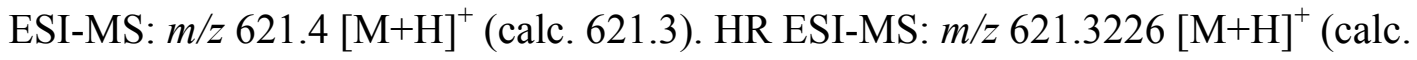
621.3224).

\subsection{4-([2,2':6',2"-Terpyridin]-4'-yl)-N,N-bis(4-isobutoxyphenyl)aniline (6)}

The method was as for 5 starting with 4'-(4-bromophenyl)-2,2':6',2"-terpyridine (113 mg, $0.290 \mathrm{mmol})$ and bis(4-isobutoxyphenyl)amine (100 mg, $0.319 \mathrm{mmol})$ and $\mathrm{NaO}^{t} \mathrm{Bu}(36.2$ 
$\mathrm{mg}, 0.377 \mathrm{mmol})$. The catalyst was $\left[\mathrm{Pd}(\mathrm{dba})_{2}\right](3.34 \mathrm{mg}, 5.80 \mu \mathrm{mol})$ and $\mathrm{P}^{t} \mathrm{Bu}_{3}(6 \mu \mathrm{L}$, $5.80 \mu \mathrm{mol})$. The product was purified by column chromatography $\left(\mathrm{SiO}_{2}\right.$, toluene:EtOAc 1:0 changing to $20: 1$ to $10: 1$ to $10: 2$ to $2: 1$ to $1: 1$ to $0: 1$ ) and compound 6 was isolated as a pale yellow solid (81.0 mg, $0.130 \mathrm{mmol}, 44.8 \%)$. M.p. $65.9{ }^{\circ} \mathrm{C} .{ }^{1} \mathrm{H}$ NMR $(500 \mathrm{MHz}$, $\left.\mathrm{THF}-d_{8}\right) \delta / \mathrm{ppm} 8.79\left(\mathrm{~s}, 2 \mathrm{H}, \mathrm{H}^{\mathrm{B} 3}\right), 8.70\left(\mathrm{~m}, 2 \mathrm{H}, \mathrm{H}^{\mathrm{A} 3}\right), 8.67(\mathrm{ddd}, J=4.8,1.9,0.9 \mathrm{~Hz}, 2 \mathrm{H}$, $\left.\mathrm{H}^{\mathrm{A} 6}\right), 7.88\left(\mathrm{~m}, 2 \mathrm{H}, \mathrm{H}^{\mathrm{A} 4}\right), 7.73\left(\mathrm{~d}, J=8.7 \mathrm{~Hz}, 2 \mathrm{H}, \mathrm{H}^{\mathrm{C} 2}\right), 7.35\left(\mathrm{~m}, 2 \mathrm{H}, \mathrm{H}^{\mathrm{A} 5}\right), 7.09(\mathrm{~d}, J=9.0$ $\left.\mathrm{Hz}, 4 \mathrm{H}, \mathrm{H}^{\mathrm{D} 2}\right), 7.03\left(\mathrm{~d}, J=8.7 \mathrm{~Hz}, 2 \mathrm{H}, \mathrm{H}^{\mathrm{C} 3}\right), 6.88\left(\mathrm{~d}, J=9.0 \mathrm{~Hz}, 4 \mathrm{H}, \mathrm{H}^{\mathrm{D} 3}\right), 3.73(\mathrm{~d}, J=6.4$ $\left.\mathrm{Hz}, 4 \mathrm{H}, \mathrm{H}^{\mathrm{OCH}_{2}}\right), 2.11\left(\mathrm{~m}, 2 \mathrm{H}, \mathrm{H}^{\mathrm{CH}}\right), 1.04\left(\mathrm{~d}, J=6.7 \mathrm{~Hz}, 12 \mathrm{H}, \mathrm{H}^{\mathrm{Me}}\right) .{ }^{13} \mathrm{C} \mathrm{NMR}(126 \mathrm{MHz}$, $\left.\mathrm{THF}-d_{8}\right) \delta / \operatorname{ppm} 157.0\left(\mathrm{C}^{\mathrm{A} 2}\right), 157.0\left(\mathrm{C}^{\mathrm{D} 4}\right), 156.6\left(\mathrm{C}^{\mathrm{B} 2}\right), 150.8\left(\mathrm{C}^{\mathrm{C} 1}\right), 150.3\left(\mathrm{C}^{\mathrm{C} 4}\right), 149.8$ $\left(\mathrm{C}^{\mathrm{A} 6}\right), 141.1\left(\mathrm{C}^{\mathrm{D} 1}\right), 137.2\left(\mathrm{C}^{\mathrm{A} 4}\right), 130.4\left(\mathrm{C}^{\mathrm{B} 4}\right), 128.3\left(\mathrm{C}^{\mathrm{C} 2}\right), 127.6\left(\mathrm{C}^{\mathrm{D} 2}\right), 124.3\left(\mathrm{C}^{\mathrm{A} 5}\right), 121.4$ $\left(\mathrm{C}^{\mathrm{A} 3}\right), 120.6\left(\mathrm{C}^{\mathrm{C} 3}\right), 118.2\left(\mathrm{C}^{\mathrm{B} 3}\right), 115.9\left(\mathrm{C}^{\mathrm{D} 3}\right), 75.0\left(\mathrm{C}^{\mathrm{OCH}}\right), 29.2\left(\mathrm{C}^{\mathrm{CH}}\right), 19.4\left(\mathrm{C}^{\mathrm{Me}}\right) . \mathrm{IR}$ (solid, $\mathrm{cm}^{-1}$ ) 2957 (w), 2916 (w), 2867 (w), 1583 (m), 1503 (vs), 1467 (m), 1234 (s), $1033(\mathrm{~m}), 825(\mathrm{~m}), 791(\mathrm{~s}), 737(\mathrm{w}), 660(\mathrm{w}), 522(\mathrm{w})$. ESI-MS: $m / z 621.6[\mathrm{M}+\mathrm{H}]^{+}$(calc. 621.3). HR ESI-MS: $m / z$ 621.3223 [M+H] $]^{+}$(calc. 621.3224).

\subsection{4-([2,2':6',2"-Terpyridin]-4'-yl)-N,N-bis(4-n-octoxyphenyl)aniline (7)}

The method was as for 5 starting with 4'-(4-bromophenyl)-2,2':6',2"-terpyridine (166 mg, $0.427 \mathrm{mmol}$ ) and 4,4'-di-n-octoxydiphenylamine (200 $\mathrm{mg}, 0.470 \mathrm{mmol}$ ) and $\mathrm{NaO}^{t} \mathrm{Bu}$ (53.4 mg, $0.555 \mathrm{mmol})$. The catalyst was $\left[\mathrm{Pd}(\mathrm{dba})_{2}\right](4.91 \mathrm{mg}, 8.54 \mu \mathrm{mol})$ and $\mathrm{P}^{t} \mathrm{Bu}_{3}(8$ $\mu \mathrm{L}, 8.54 \mu \mathrm{mol})$. The product was purified by column chromatography $\left(\mathrm{SiO}_{2}\right.$, toluene:EtOAc 1:0 changing to $10: 1$ to $10: 4$ to $2: 1$ to $1: 1$ to $0: 1$ ) and 7 was isolated as a pale yellow oily-solid (250 mg, $0.341 \mathrm{mmol}, 79.9 \%) .{ }^{1} \mathrm{H} \mathrm{NMR}\left(500 \mathrm{MHz}, \mathrm{CDCl}_{3}\right) \delta /$ ppm $8.72\left(\mathrm{ddd}, J=4.8,1.8,0.9 \mathrm{~Hz}, 2 \mathrm{H}, \mathrm{H}^{\mathrm{A} 6}\right), 8.68\left(\mathrm{~s}, 2 \mathrm{H}, \mathrm{H}^{\mathrm{B} 3}\right), 8.65\left(\mathrm{~m}, 2 \mathrm{H}, \mathrm{H}^{\mathrm{A} 3}\right), 7.86$ $\left(\mathrm{m}, 2 \mathrm{H}, \mathrm{H}^{\mathrm{A} 4}\right), 7.74\left(\mathrm{~d}, J=8.8 \mathrm{~Hz}, 2 \mathrm{H}, \mathrm{H}^{\mathrm{C} 2}\right), 7.34\left(\mathrm{ddd}, J=7.5,4.8,1.2 \mathrm{~Hz}, 2 \mathrm{H}, \mathrm{H}^{\mathrm{A} 5}\right)$, $7.10\left(\mathrm{~d}, J=8.9 \mathrm{~Hz}, 4 \mathrm{H}, \mathrm{H}^{\mathrm{D} 2}\right), 7.01\left(\mathrm{~d}, J=8.8 \mathrm{~Hz}, 2 \mathrm{H}, \mathrm{H}^{\mathrm{C} 3}\right), 6.85\left(\mathrm{~d}, J=8.9 \mathrm{~Hz}, 4 \mathrm{H}, \mathrm{H}^{\mathrm{D} 3}\right)$, 
$3.95\left(\mathrm{t}, J=6.6 \mathrm{~Hz}, 4 \mathrm{H}, \mathrm{H}^{\mathrm{OCH}_{2}}\right), 1.79\left(\mathrm{~m}, 4 \mathrm{H}, \mathrm{H}^{\mathrm{OCH}_{2} \mathrm{CH}_{2}}\right), 1.47\left(\mathrm{~m}, 4 \mathrm{H}, \mathrm{H}^{\mathrm{OCH}_{2} \mathrm{CH}_{2} \mathrm{CH}_{2}}\right)$, $1.40-1.26\left(\mathrm{~m}, 16 \mathrm{H}, \mathrm{H}^{\mathrm{CH} 2}\right), 0.90\left(\mathrm{~m}, 6 \mathrm{H}, \mathrm{H}^{\mathrm{Me}}\right) .{ }^{13} \mathrm{C} \mathrm{NMR}\left(126 \mathrm{MHz}, \mathrm{CDCl}_{3}\right) \delta / \mathrm{ppm}$ $156.7\left(\mathrm{C}^{\mathrm{A} 2}\right), 155.9\left(\mathrm{C}^{\mathrm{D} 4+\mathrm{B} 2}\right), 150.0\left(\mathrm{C}^{\mathrm{C} 4 / \mathrm{C} 1}\right), 149.9\left(\mathrm{C}^{\mathrm{C} 4 / \mathrm{C} 1}\right), 149.2\left(\mathrm{C}^{\mathrm{A} 6}\right), 140.4\left(\mathrm{C}^{\mathrm{D} 1}\right)$, $137.0\left(\mathrm{C}^{\mathrm{A} 4}\right), 129.6\left(\mathrm{C}^{\mathrm{B} 4}\right), 128.0\left(\mathrm{C}^{\mathrm{C} 2}\right), 127.1\left(\mathrm{C}^{\mathrm{D} 2}\right), 123.8\left(\mathrm{C}^{\mathrm{A} 5}\right), 121.5\left(\mathrm{C}^{\mathrm{A} 3}\right), 120.0\left(\mathrm{C}^{\mathrm{C} 3}\right)$, $118.1\left(\mathrm{C}^{\mathrm{B} 2}\right), 115.5\left(\mathrm{C}^{\mathrm{D} 3}\right), 68.4\left(\mathrm{C}^{\mathrm{OCH} 2}\right), 32.0\left(\mathrm{C}^{\mathrm{CH} 2}\right), 29.6\left(\mathrm{C}^{\mathrm{CH} 2}\right), 29.5\left(\mathrm{C}^{\mathrm{OCH}_{2} \mathrm{CH}_{2}}\right), 29.4$ $\left(\mathrm{C}^{\mathrm{CH}} 2\right), 26.3\left(\mathrm{C}^{\mathrm{OCH}_{2} \mathrm{CH}_{2} \mathrm{CH}_{2}}\right), 22.8\left(\mathrm{C}^{\mathrm{CH}}\right), 14.3\left(\mathrm{C}^{\mathrm{Me}}\right)$. IR (solid, $\left.\mathrm{cm}^{-1}\right) 2924(\mathrm{~m}), 2854(\mathrm{w})$, 1599 (w), 1583 (m), 1503 (vs), 1467 (m), 1235 (s), 826 (s), 792 (s), 738 (m), 660 (m), 521 (m). ESI-MS: $m / z 733.7[\mathrm{M}+\mathrm{H}]^{+}$(733.4), $755.7[\mathrm{M}+\mathrm{Na}]^{+}$(755.4). HR ESI-MS: $\mathrm{m} / z$ $733.4482[\mathrm{M}+\mathrm{H}]^{+}$(calc. 733.4476), $755.4300[\mathrm{M}+\mathrm{Na}]^{+}$(calc. 755.4295).

\subsection{DSSC fabrication}

DSSCs were prepared based on the procedure of Grätzel and coworkers [28,29]. Solaronix Test Cell Titania Electrodes with a scattering layer were used for the photoanodes. The electrodes were sintered at $450{ }^{\circ} \mathrm{C}$ for $30 \mathrm{~min}$, cooled to ca. $80{ }^{\circ} \mathrm{C}$ and then soaked in a DMSO solution of 3 or $\mathbf{4}(1 \mathrm{mM})$ for $24 \mathrm{~h}$. The colourless slides were then removed from the solution, washed with DMSO and EtOH, and dried. Then, the electrodes were soaked in an $\mathrm{EtOH}$ solution of $\mathrm{ZnCl}_{2}(0.5 \mathrm{mM})$ for $24 \mathrm{~h}$, and after washing with EtOH and drying, were immersed in a $\mathrm{CH}_{2} \mathrm{Cl}_{2}$ solution of ligands $\mathbf{5}, \mathbf{6}$ or $\mathbf{7}$ $(0.5 \mathrm{mM})$ for $64 \mathrm{~h}$. The now orange electrodes were washed with $\mathrm{CH}_{2} \mathrm{Cl}_{2}$ and dried. Solaronix Test Cell Platinum Electrodes were used for the counter electrodes, and cleaned of volatile impurities by heating at $450{ }^{\circ} \mathrm{C}$ for $30 \mathrm{~min}$. The DSSC was assembled by combining the electrodes using thermoplast hot-melt sealing foil (Solaronix Test Cell Gaskets) and pressing them together. The electrolyte was introduced into the DSSC by vacuum backfilling and comprised LiI $(0.1 \mathrm{M}), \mathrm{I}_{2}(0.05 \mathrm{M}), 1$-methylbenzimidazole $(0.5$ M) and 1-butyl-3-methylimidazolinium iodide (0.6 M) in 3-methoxypropionitrile. The 
hole in the counter electrode was sealed using hotmelt sealing foil (Solaronix Test Cell Sealings) and a coverglass (Solaronix Test Cell Caps).

Electrodes for solid state absorption measurements were prepared in the same way as the photoanodes (above) using Solaronix transparent Test Cell Titania Electrodes without a scattering layer.

\subsection{DSSC and external quantum efficiency (EQE) measurements}

The DSSC measurements were carried out using fully masked cells; the mask comprised a black-coloured copper sheet with one aperture of average area $0.06012 \mathrm{~cm}^{2}$ (standard deviation of $1 \%$ ) placed over the active area of the cell. The area of the aperture in the mask was smaller than the surface area of $\mathrm{TiO}_{2}\left(0.36 \mathrm{~cm}^{2}\right)$. Black tape was applied to complete the masking of the cell. Measurements were made by irradiating the DSSC from behind using a SolarSim 150 instrument $\left(100 \mathrm{~mW} \mathrm{~cm}^{-2}=1 \mathrm{sun}\right)$, and the simulated light power was calibrated by using a silicon reference cell.

The external quantum efficiency (EQE) measurements were performed on a SpeQuest quantum efficiency setup from Rera Systems (Netherlands) equipped with a $100 \mathrm{~W}$ halogen lamp (QTH) and a lambda 300 grating monochromator from Lot Oriel. The monochromatic light was modulated to $3 \mathrm{~Hz}$ using a chopper wheel from ThorLabs. The cell response was amplified with a large dynamic range IV converter from CVI Melles Griot and then measured with a SR830 DSP Lock-In amplifier from Stanford Research.

\section{Results and discussion}

\subsection{Ligand syntheses and characterizations}

The synthetic routes to compounds 5-7 is summarized in Scheme 3. The secondary amine precursors were prepared by a CuI/L-proline catalysed [23] Ullmann coupling, and sebsequent Hartwig-Buchwald amination with 4'-(4-bromophenyl)-2,2':6',2"-terpyridine 
yielded compounds 5-7 in moderate to high yields. In the electrospray mass spectra of the compounds, peaks assigned to $[\mathrm{M}+\mathrm{H}]^{+}$were observed at $\mathrm{m} / \mathrm{z} 621.4$ for $\mathbf{5}, 621.6$ for $\mathbf{6}$ and 733.7 for 7 . Satisfactory elemental analyses could not be obtained, but there was good agreeent between the observed and calculated $\mathrm{m} / \mathrm{z}$ values in the high resolution mass spectra of 5-7 (see experimental section). Figure 1 shows a representative ${ }^{1} \mathrm{H}$ NMR spectrum (of compound 5); minor organic impurities observed in the ${ }^{1} \mathrm{H}$ NMR spectra persisted in all compounds after chromatographic workup. The ${ }^{1} \mathrm{H}$ and ${ }^{13} \mathrm{C}$ NMR spectra were assigned by COSY, NOESY, DEPT, HMQC and HMBC methods. NOESY crosspeaks between signals for $\mathrm{H}^{\mathrm{B} 3} / \mathrm{H}^{\mathrm{C} 2}$ and between $\mathrm{H}^{\mathrm{C} 3} / \mathrm{H}^{\mathrm{D} 2}$ allowed the pairs $\mathrm{H}^{\mathrm{C} 2} / \mathrm{H}^{\mathrm{C} 3}$ and $\mathrm{H}^{\mathrm{D} 2} / \mathrm{H}^{\mathrm{D} 3}$ to be distinguished (see Scheme 3 for atom labelling). The spectra were consistent with the structures shown in Scheme 3.

$<$ Figure 1 here $>$

\subsection{Solid state absorption spectra of $\mathrm{TiO}_{2}$-adsorbed zinc(II)-containing dyes}

Electrodes for solid state absorption measurements were prepared by stepwise dipping of commercial $\mathrm{FTO} / \mathrm{TiO}_{2}$ electrodes without a scattering layer into solutions of (i) anchoring ligands 3 or 4, (ii) zinc(II) chloride, and (iii) ancillary ligands 5, 6 or 7. Details of solvents and soaking times are given in the experimental section. After the electrodes had been washed and dried, transmission absorption spectra were recorded. The spectra were corrected with respect to a spectrum of a blank electrode. Absorption maxima are given in Table 1; a small blue-shift of the ILCT band is observed on changing the anchoring domain from carboxylic acid to phosphonic acid. Figure 2 compares the spectra of one pair of dyes with a common ancillary ligand (6) but different anchoring ligands (carboxylic acid $\mathbf{3}$ versus phosphonic acid $\mathbf{4}$ ), and also compares the series of dyes with a common anchoring ligand (4). An increase in absorbance is seen comparing $[\mathrm{Zn}(\mathbf{3})(\mathbf{6})]^{2+}$ to $[\operatorname{Zn}(\mathbf{4})(\mathbf{6})]^{2+}$, a trend also observed on going from $[\operatorname{Zn}(\mathbf{3})(\mathbf{5})]^{2+}$ to $[\operatorname{Zn}(\mathbf{4})(\mathbf{5})]^{2+}$, and 
from $[\mathrm{Zn}(3)(7)]^{2+}$ to $[\mathrm{Zn}(4)(7)]^{2+}$. Although not definitive, the data are consistent with enhanced surface coverage by the phosphonic acid anchoring ligand compared to the carboxylic acid. Figure 2 reveals that with a constant anchor $\mathbf{4}$, the absorbance of the functionalized titania decreases as the ancillary ligand is changed from 5 to 6 to 7 , and the same trend is observed for the series $[\operatorname{Zn}(\mathbf{3})(\mathbf{5})]^{2+}>[\operatorname{Zn}(\mathbf{3})(\mathbf{6})]^{2+}>[\operatorname{Zn}(\mathbf{3})(\mathbf{7})]^{2+}$. This follows the order of the steric demands of the alkoxy-substituents, implying that fewer surface coordination sites can be occupied as the steric demand of the ancillary ligand increases.

$<$ Figure 2 here $>$

$<$ Table 1 here $>$

\subsection{EQE spectra}

DSSCs were assembled by the stepwise process described above, using commercial electrodes with a scattering layer (see Experimental section). In addition to ancillary ligands 5-7, DSSCs were also fabricated using ancillary ligand 2 which contains methoxy substituents (Scheme 1). After immersion in the dye bath containing $\mathbf{2 , 5 , 6}$ or $\mathbf{7}$, the electrodes changed from colourless to orange. Previously, we have reported efficiency data for $\mathrm{TiO}_{2}$-supported dyes $[\mathrm{Zn}(\mathbf{3})(\mathbf{2})]^{2+}$ and $[\mathrm{Zn}(\mathbf{4})(\mathbf{2})]^{2+}$ in unmasked DSSCs [12]. More recently, we have made the transition to fully masked [16] DSSCs, and we have reinvestigated the performances of masked cells incorporating $[\operatorname{Zn}(3)(2)]^{2+}$ and $[\mathrm{Zn}(4)(2)]^{2+}$ to allow a direct comparison with dyes containing the alkoxy tails. Duplicate DSSCs were made for each sensitizer.

External quantum efficiency (EQE) spectra for the DSSCs were recorded and Figure 3a shows spectra for cells containing $[\operatorname{Zn}(4)(2)]^{2+},[\operatorname{Zn}(4)(5)]^{2+},[\operatorname{Zn}(4)(6)]^{2+}$ and 
$[\mathrm{Zn}(4)(7)]^{2+}$ with the phosphonic acid anchor. Figure $3 \mathrm{~b}$ shows the EQE spectrum of a reference DSSC containing the ruthenium(II) dye N719. Despite the orange colour of the zinc(II)-containing electrodes and their solid state absorption spectra, both of which confirm light-harvesting in the visible region, the EQE spectra in Figure 3a reveal extremely poor electron injection. The $\mathrm{EQE}_{\max }$ are $<1.4 \%$ at $\lambda_{\max }=430-450 \mathrm{~nm}$ for all the DSSCs, and the corresponding values for DSSCs containing $[\operatorname{Zn}(\mathbf{3})(\mathbf{2})]^{2+}$, $[\operatorname{Zn}(\mathbf{3})(\mathbf{5})]^{2+},[\mathrm{Zn}(\mathbf{3})(\mathbf{6})]^{2+}$ and $[\mathrm{Zn}(\mathbf{3})(7)]^{2+}$ (carboxylic acid anchors) are even lower $(<1.0 \%)$. Nonetheless, we note that the introduction of the alkoxy chains has a beneficial effect, further substantiated by the DSSC parameters discussed below. For comparison, the EQE spectrum of the N719 reference cell (Figure 3b) is characterized by $\mathrm{EQE}_{\max }$ of $67.5 \%$ at $\lambda_{\max }=540$ extending to a high energy shoulder $\left(\lambda_{\max }=410 \mathrm{~nm}\right)$ with $\mathrm{EQE}_{\max }=$ $54.3 \%$.

$<$ Figure 3 here $>$

\subsection{DSSC performances}

Performance characteristics of DSSCs containing the $\left\{\mathrm{Zn}(\operatorname{tpy})_{2}\right\}^{2+}$ dyes measured on the day of assembling the cells are shown in Tables 2 and 3. Duplicate cells were prepared for each dye and the data are compared to those measured for an N719 cell; the DSSCs correspond to those used for the EQE spectra discussed above. Data in Tables 2 and 3 refer to dyes containing the phosphonic and carboxylic acid anchors $\mathbf{4}$ and $\mathbf{3}$, respectively. It is important to note the reproducibility of data for pairs of duplicate cells which lends credence to the data, despite the poor efficiencies. Control measurements were made using a blank electrode (i.e. no adsorbed anchoring ligand or dye), yielding values of the short-circuit current density $\left(J_{\mathrm{SC}}\right) \approx 0.3 \mathrm{~mA} \mathrm{~cm}^{-2}$, open-circuit voltage $\left(V_{\mathrm{OC}}\right) \approx 460 \mathrm{mV}$ 
and an efficiency $(\eta) \approx 0.10 \%$. Thus, detailed discussion of the performance parameters is not justified and we focus only on trends.

A critical observation is the effect of masking the DSSC containing the dyes $[\operatorname{Zn}(3)(2)]^{2+}$ and $[\operatorname{Zn}(4)(2)]^{2+}$. With unmasked DSSCs efficiencies of 0.46 and $0.63 \%$ are observed, respectively[12], but a fall to $<0.05 \%$ occurs upon masking (Tables 2 and 3 ). This is consistent with previous comparisons of masked and unmasked DSSCs containing copper(I)-based dyes [30].

A comparison of Tables 2 and 3 suggests that the phosphonic acid anchoring ligand $\mathbf{4}$ is favoured over the dicarboxylic acid anchor $\mathbf{3}$, an observation that has been noted by Grätzel [31] and is also true for copper(I) dyes [10,30,32]. However, for both anchoring domains, values of $J_{\mathrm{SC}}$ show that electron injection is extremely poor. This is consistent with the EQE spectra, and is the dominant factor leading to the meagre global efficiencies of $\left\{\mathrm{Zn}\left(\mathrm{tpy}_{\text {anchor }}\right)\left(\text { tpy }_{\text {ancillary }}\right)\right\}^{2+}$ dyes. Replacing methoxy substituents by butoxy groups on the periphery of the ancillary ligand results in an enhancement in both $J_{\mathrm{SC}}$ and $V_{\mathrm{OC}}$, and a consequent gain in the efficiency. For both $\mathbf{3}$ and $\mathbf{4}$, the trend in DDSC performances follows the order of ancillary substituents n-butyl $>$ isobutyl $>$ octyl $>$ methyl. This is consistent with the solid state absorption maxima of dye-functionalized electrodes for which the intensities are $\left[\mathrm{Zn}\left(\operatorname{tpy} y_{\text {anchor }}\right)(\mathbf{5})\right]^{2+}>\left[\mathrm{Zn}\left(\operatorname{tpy} y_{\text {anchor }}\right)(\mathbf{6})\right]^{2+}>$ $\left[\mathrm{Zn}\left(\text { tpy }_{\text {anchor }}\right)(\mathbf{7})\right]^{2+}$ both for tpy $y_{\text {anchor }}=\mathbf{3}$ and $\mathbf{4}$ (Figure 2$)$.

$<$ Tables 2 and 3 here $>$ 
An atom-efficient stepwise assembly procedure has been developed for functionalization of $\mathrm{FTO} / \mathrm{TiO}_{2}$ electrodes with $\left\{\mathrm{Zn}\left(\text { tpy } \mathrm{tanch}_{\mathrm{a}}\right)\left(\text { tpy }_{\text {ancillary }}\right)\right\}^{2+}$ dyes incorporating chromophoric ancillary ligands $2,5,6$ and 7 . The intensities of the solid-state absorption maxima of the dye-functionalized $\mathrm{TiO}_{2}$ decrease in the order $[\mathrm{Zn}(\mathbf{3})(\mathbf{5})]^{2+}>[\mathrm{Zn}(\mathbf{3})(\mathbf{6})]^{2+}$ $>[\operatorname{Zn}(3)(7)]^{2+}$, and $[\operatorname{Zn}(\mathbf{4})(5)]^{2+}>[\operatorname{Zn}(\mathbf{4})(6)]^{2+}>[\operatorname{Zn}(4)(7)]^{2+}$. Assuming that equal soaking times in solutions of an anchoring ligand results in similar surface coverages, this is consistent with fewer surface sites being occupied (bottom of Scheme 1) as the steric demand of the ancillary ligand increases. Despite the absorption properties of the dyes, DSSC measurements reveal poor photon-to-current conversion efficiencies. A major contributing factor is the poor electron injection, seen in low values of $J_{\mathrm{SC}}$ and $\mathrm{EQE}$ max. Introducing alkoxy chains (in 5, 6 and 7) into the hole-transporting domains in tpy ancillary is beneficial, and leads to increased $J_{\mathrm{SC}}$ and $V_{\mathrm{OC}}$, although absolute values remain low.

\section{Acknowledgements}

The project is supported by the European Research Council (Advanced Grant 267816 LiLo), the Swiss National Science Foundation (200020_144500) and the University of Basel. We thank M. Waser, FHNW, Basel for the preparation of ligand 4, and Dr Collin Morris and Dr Heinz Nadig for recording LC-ESI and HR-ESI mass spectra.

\section{References}

[1] Mishra A, Fischer M K R, Bäuerle P. Metal-free organic dyes for dye-sensitzed solar cells: From structure-property relationships to design rules. Angew. Chem. Int. Ed. 2009; 48; 2474-2499.

[2] Kalyanasundaram, K. ed. 'Dye-Sensitized Solar Cells', CRC Press, Taylor \& Francis, Boca Raton, 2010. 
[3] Vougioukalakis G C, Philippopoulos A I, Stergiopoulos T, Falaras P. Contributions to the development of ruthenium-based sensitizers for dyesensitized solar cells. Coord. Chem. Rev. 2011; 255; 2602-2621.

[4] Bozic-Weber B, Constable E C, Housecroft C E. Light harvesting with Earth abundant $d$-block metals: towards a sustainable materials chemistry. Coord. Chem. Rev. 2013; 257; 3089-3106.

[5] Alonso-Vante N, Nierengarten J-F, Sauvage J-P. Spectral sensitization of largeband-gap semiconductors (thin films and ceramics) by a carboxylated bis $(1,10$ phenanthroline)copper(I) complex. J. Chem. Soc. Dalton Trans. 1994; 1649-1654.

[6] Sandroni M, Favereau L, Planchat A, Akdas-Kilig H, Szuwarski N, Pellegrin Y, Blart E, Le Bozec H, Boujtita M, Odobel F. Heteroleptic copper(I)-polypyridine complexes as efficient sensitizers for dye sensitized solar cells. J. Mater. Chem. A 2014; 2; 9944-9947.

[7] Schmittel M, Luning U, Meder M, Ganz A, Michel C, Herderich M. Synthesis of sterically encumbered 2,9-diaryl substituted phenthrolines. Key building blocks for the preparation of mixed (bis-heteroleptic) phenanthroline copper(I) complexes. Heterocycl. Commun. 1997; 3; 493-498.

[8] Sandroni M, Kayanuma M, Planchat A, Szuwarski N, Blart E, Pellegrin Y, Daniel C, Boujtita M, Odobel, F. First application of the HETPHEN concept to new heteroleptic bis(diimine) copper(I) complexes as sensitizers in dye sensitized solar cells. Dalton Trans. 2013; 42; 10818-10827.

[9] Schönhofer E, Bozic-Weber B, Martin C J, Constable E C, Housecroft C E, Zampese J. A. 'Surfaces-as-ligands, surfaces-as-complexes' strategies for copper(I) dye-sensitized solar cells. Dyes and Pigments, submitted, DYPI-D-1401110. 
[10] Bozic-Weber B, Constable E C, Housecroft C E, Kopecky P, Neuburger M, Zampese $\mathrm{J}$ A. The intramolecular aryl embrace: from light emission to light absorption. Dalton Trans. 2011; 40; 12584-12594.

[11] Brauchli S Y, Malzner F J, Constable E C, Housecroft C E. Influence of a coadsorbant on the performance of bis(diimine) copper(I)-based dye-sensitized solar cells. RSC Adv. 2014; 4; 62728-62736.

[12] Bozic-Weber B, Constable E C, Hostettler N, Housecroft C E, Schmitt R, Schönhofer E. The $d^{10}$ route to dye-sensitized solar cells: step-wise assembly of zinc(II) photosensitizers on $\mathrm{TiO}_{2}$ Surfaces. Chem. Commun. 2012; 48; 57275729.

[13] Griffith M J, Sunahara K, Wagner P, Wagner K, Wallace G G, Officer D L, Furube A, Katoh R, Mori S, Mozer A J. Porphyrins for dye-sensitized solar cells: new insights into efficiency-determining electron transfer steps. Chem. Commun. 2012; $48 ; 4145-4162$.

[14] Yella A, Lee H-W, Tsao H N, Yi C, Chandiran A K, Nazeeruddin Md K, Diau E W. G, Yeh C-Y, Zakeeruddin S M, Grätzel M. Porphyrin-sensitized solar cells with cobalt(II)/(III)-based redox electrolyte exceed 12 percent efficiency. Science; 2011; $334 ; 629-634$.

[15] K. A. Walters, Y.-J. Kim, J. T. Hupp, J. Electroanal. Chem. 554-555 (2003) 449.

[16] Snaith H J. How should you measure your excitonic solar cells? Energy Environ. Sci. 2012; 5; 6513-6520.

[17] Kroeze J E, Hirata N, Koops S, Nazeeruddin Md K, Schmidt-Mende L, Grätzel M, Durrant J R. Alkyl chain barrier for kinetic optimization in dye-sensitized solar cells. J. Am. Chem. Soc. 2006; 128; 16376-16383. 
[18] Koumura N, Wang Z-S, Mori S, Miyashita M, Suzuki E, Hara K. Alkylfunctionalized organic dyes for efficient molecular photovoltaics. J. Am. Chem. Soc. $2006 ; 128 ; 14256-14257$.

[19] Chang Y-C, Wang C-L, Pan T-Y, Hong S-H, Lan C-M, Kuo H-H, Lo C-F, Hsu HY, Lin C-Y, Diau E W-G. A strategy to design highly efficient porphyrin sensitizers for dye-sensitized solar cells. Chem. Commun. 2011; 47; 8910-8912.

[20] Xue X, Zhang W, Zhang N, Ju C, Peng X, Yang Y, Liang Y, Feng Y, Zhang B. Effect of the length of the alkyl chains in porphyrin meso-substituents on the performance of dye-sensitized solar cells. RSC Adv. 2014; 4; 8894-8900.

[21] Suresh T, Ganesh K, Singh S P, Islam A, Han L, Chandrasekharam M. Functionalized phenyl bipyridine ancillary ligand as double recombination inhibitor in ruthenium complex for dye solar cells. Dyes and Pigments 2013; 99; 850-856.

[22] Wang J, Hanan G S. A facile route to sterically hindered and non-hindered 4'-aryl$2,2^{\prime}: 6^{\prime}, 2^{\prime \prime}$-terpyridines. Synlett $205 ; 1251-1254$.

[23] Shallaiah M, Rajan Y C, Lin H-C. Synthesis of novel triarylamine-based dendrimers with $\mathrm{N}^{4}, \mathrm{~N}^{6}$-dibutyl-1,3,5-triazine-4,6-diamine probe for electron/energy transfers in H-bonded donor-acceptor-donor triads and as efficient $\mathrm{Cu}^{2+}$ sensors. J. Mater. Chem. 2012; 22; 8976-8987.

[24] Odom S A, Lancaster K, Beverina L, Lefler K M, Thompson N J, Coropceanu V, Brédas J-L, Marder S R, Barlow S. Bis[bis-(4-alkoxyphenyl)amino] derivatives of dithienylethene, bithiophene, dithienothiophene and dithienopyrrole: Palladiumcatalysed synthesis and highly delocalised radical cations. Chem. Eur. J. 2007; 34; 9637-9646. 
[25] Blasco E, Schmidt B V K J, Barner-Kowollik C, Piñol M, Oriol L. Dual thermoand photo-responsive micelles based on miktoarm star polymers. Polymer Chem. $2013 ; 4 ; 4506-4514$.

[26] Vasconcelos U B, Schrader A, Vilela G D, Borges A C A, Merlo A A. Buchwald protocol applied to the synthesis of $N$-heterotolan liquid crystals. Tetrahedron 2008; $64 ; 4619-4626$.

[27] Kim D-Y, Lee S-A, Choi Y-J, Hwang S-H, Kuo S-W, Nah C, Lee M-H, Jeong KU. Thermal- and photo-induced phase-transition behaviors of a tapered dendritic liquid crystal and photochromic azobenzene mesogens and a bicyclic chiral center. Chem. Eur. J. 2014; 20; 5689-5695.

[28] Ito S, Murakami T N, Comte P, Liska P, Grätzel C, Nazeeruddin M K, Grätzel M. Fabrication of thin film dye sensitized solar cells with solar to electric power conversion efficiency over 10\%. Thin Solid Films 2008; 516; 4613-4619.

[29] Ito S, Chen P, Comte P, Nazeeruddin M K, Liska P, Péchy P, Grätzel M, Fabrication of screen-printing pastes from $\mathrm{TiO}_{2}$ powders for dye-sensitised solar cells. Prog. Photovoltaics Res. Appl. 2007; 15; 603-612.

[30] Bozic-Weber B, Brauchli S Y, Constable E C, Fürer S O, Housecroft C E, Wright I A. Hole-transport functionalized copper(I) dye sensitized solar cells. Phys. Chem. Chem. Phys. 2013; 15; 4500-4504.

[31] Péchy P, Rotzinger F P, Nazeeruddin Md K, Kohle O, Zakeeruddin S M, HumphryBaker R, Grätzel M. Preparation of phosphonated polypyridyl ligands to anchor transition-metal complexes on oxide surfaces: Application for the conversion of light to electricity with nanocrystalline $\mathrm{TiO}_{2}$ films. J. Chem. Soc., Chem. Commun. 1995; 65-66. 
[32] Bozic-Weber B, Chaurin V, Constable E C, Housecroft C E, Meuwly M, Neuburger M, Rudd J A, Schönhofer E, Siegfried L. Exploring copper(I)-based dye-sensitized solar cells: a complementary experimental and TD-DFT investigation. Dalton Trans. 2012; 41; 14157-141169.

Figure and scheme captions

Scheme 1. 'Surfaces-as-ligands' approach to the assembly of copper(I) and zinc(II)-based dyes. For the copper(I) dyes, the ligands are diimines (e.g. derivatives of 2,2'bipyridine) and for the zinc(II) dyes, the ligands are 4'-functionalized 2,2':6',2"terpyridines.

Scheme 2. Structures of ancillary ligands $1,2,5-7$, and anchoring ligands 3 and 4 .

Scheme 3. Synthesis of 5-7. Conditions: (i) $\mathrm{K}_{2} \mathrm{CO}_{3}$, CuI, L-proline in DMSO, $90{ }^{\circ} \mathrm{C}, 4$ days; (ii) 4'-(4-bromophenyl)-2,2':6',2"-terpyridine, $\mathrm{NaO}^{t} \mathrm{Bu}, \mathrm{Pd}(\mathrm{bda})_{2} / \mathrm{P}^{t} \mathrm{Bu}_{3}$, toluene, 20 hours. Atom labels refer to NMR spectroscopic assignments.

Figure 1. $500 \mathrm{MHz}{ }^{1} \mathrm{H} \mathrm{NMR}$ spectrum of compound 5; chemical shifts in $\partial / \mathrm{ppm}$. * = residual $\mathrm{CHCl}_{3} ; \times=\mathrm{H}_{2} \mathrm{O} ; \mathbf{0}=$ traces of ethyl acetate.

Figure 2. Solid state absorption spectra of electrodes (without scattering layer) with adsorbed dyes $[\mathrm{Zn}(\mathbf{4})(\mathbf{5})]^{2+},[\mathrm{Zn}(\mathbf{4})(\mathbf{6})]^{2+},[\mathrm{Zn}(\mathbf{4})(\mathbf{7})]^{2+}$ and $[\mathrm{Zn}(\mathbf{3})(\mathbf{6})]^{2+}$. 
Figure 3. (a) EQE spectra of DSSCs containing the dyes $[\mathrm{Zn}(\mathbf{4})(\mathbf{2})]^{2+},[\mathrm{Zn}(\mathbf{4})(\mathbf{5})]^{2+}$, $[\mathrm{Zn}(4)(6)]^{2+}$ and $[\mathrm{Zn}(4)(7)]^{2+}$. (b) EQE spectrum of reference DSSC containing standard dye N719.

Figures and schemes

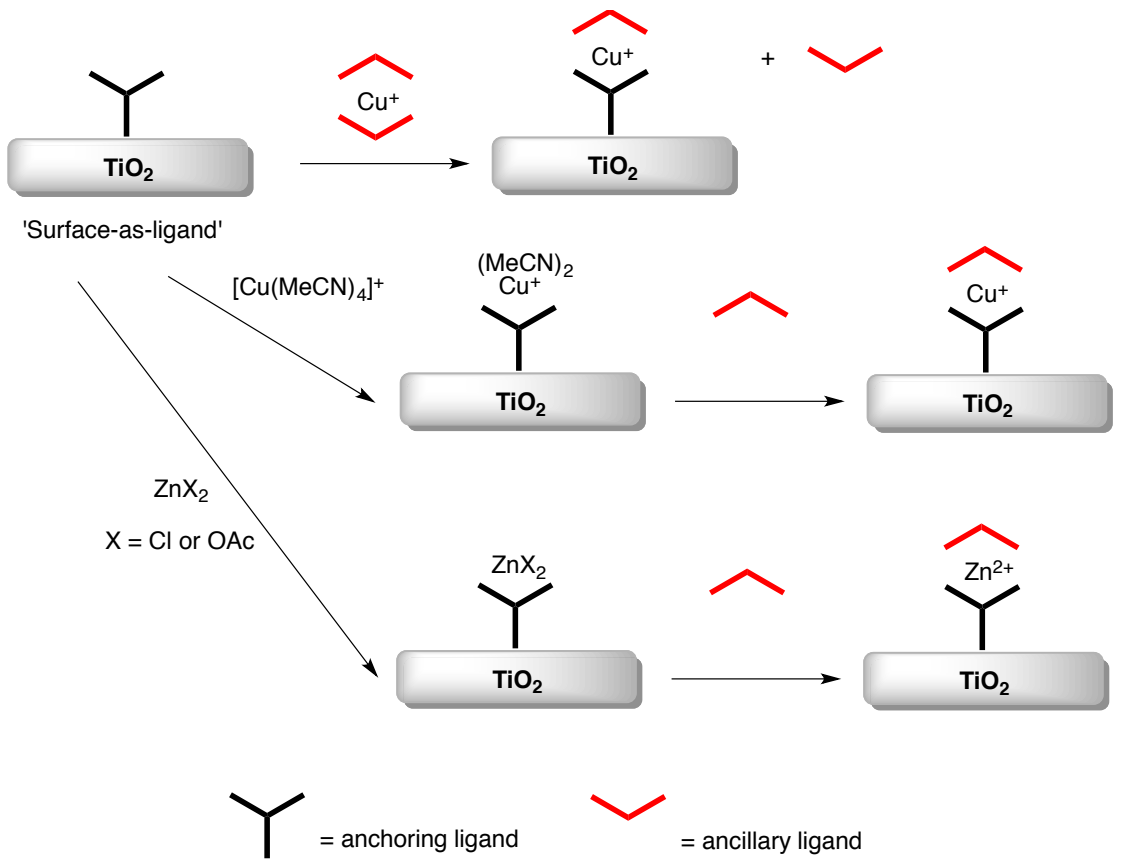

Scheme 1.<smiles>Pc1ccc(N(c2ccc(P)cc2)c2ccc(-c3cc(-c4ccccn4)nc(-c4ccccn4)c3)cc2)cc1</smiles>

$1 \mathrm{R}=\mathrm{H}$

$2 \mathrm{R}=\mathrm{OMe}$

$5 \mathrm{R}=\mathrm{O}^{\mathrm{n}} \mathrm{Bu}$

$6 \mathrm{R}=\mathrm{O}^{\text {iso }} \mathrm{Bu}$

$7 \mathrm{R}=\mathrm{O}^{\mathrm{n}}$ octyl<smiles>O=C(O)c1ccc(-c2cc(-c3ccccn3)nc(-c3ccccn3)c2)cc1C(=O)O</smiles>

3<smiles>O=C(O)c1ccc(-c2cc(-c3ccccn3)nc(-c3ccccn3)c2)cc1</smiles>

4 
Scheme 2.

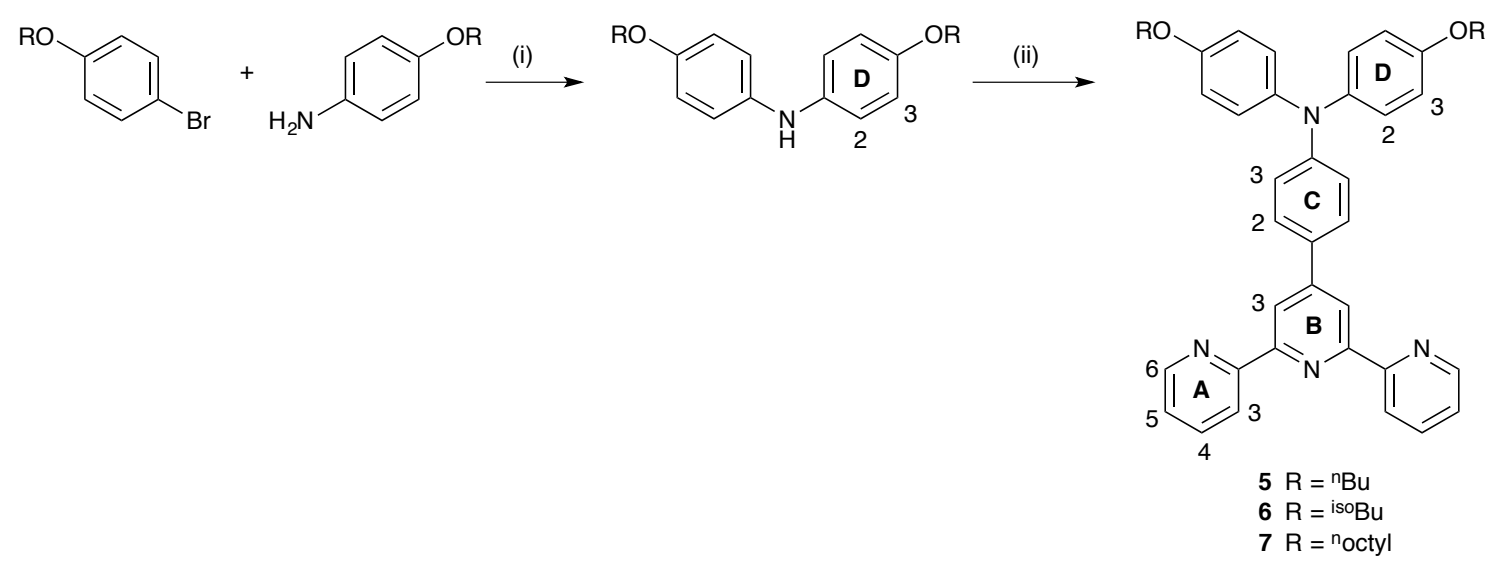

Scheme 3.

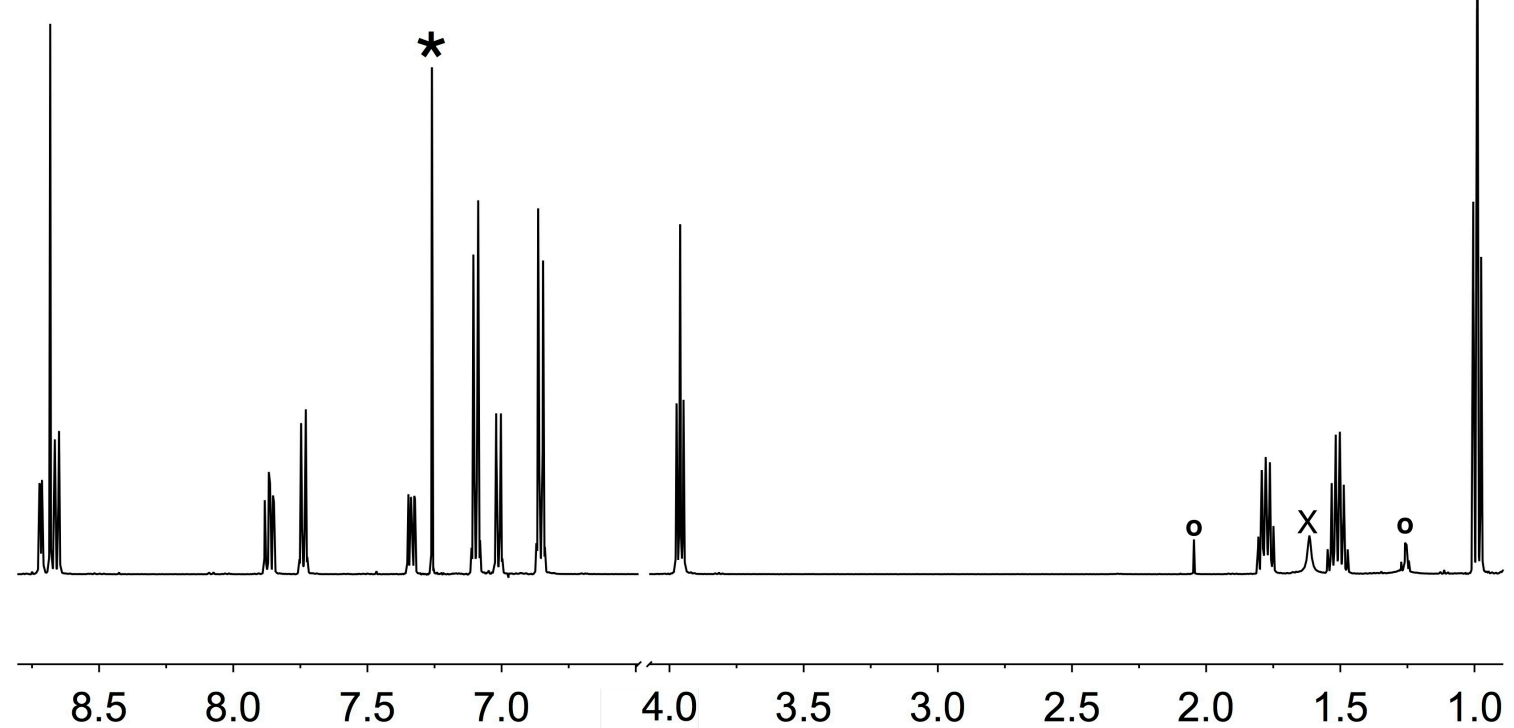

Figure 1. 


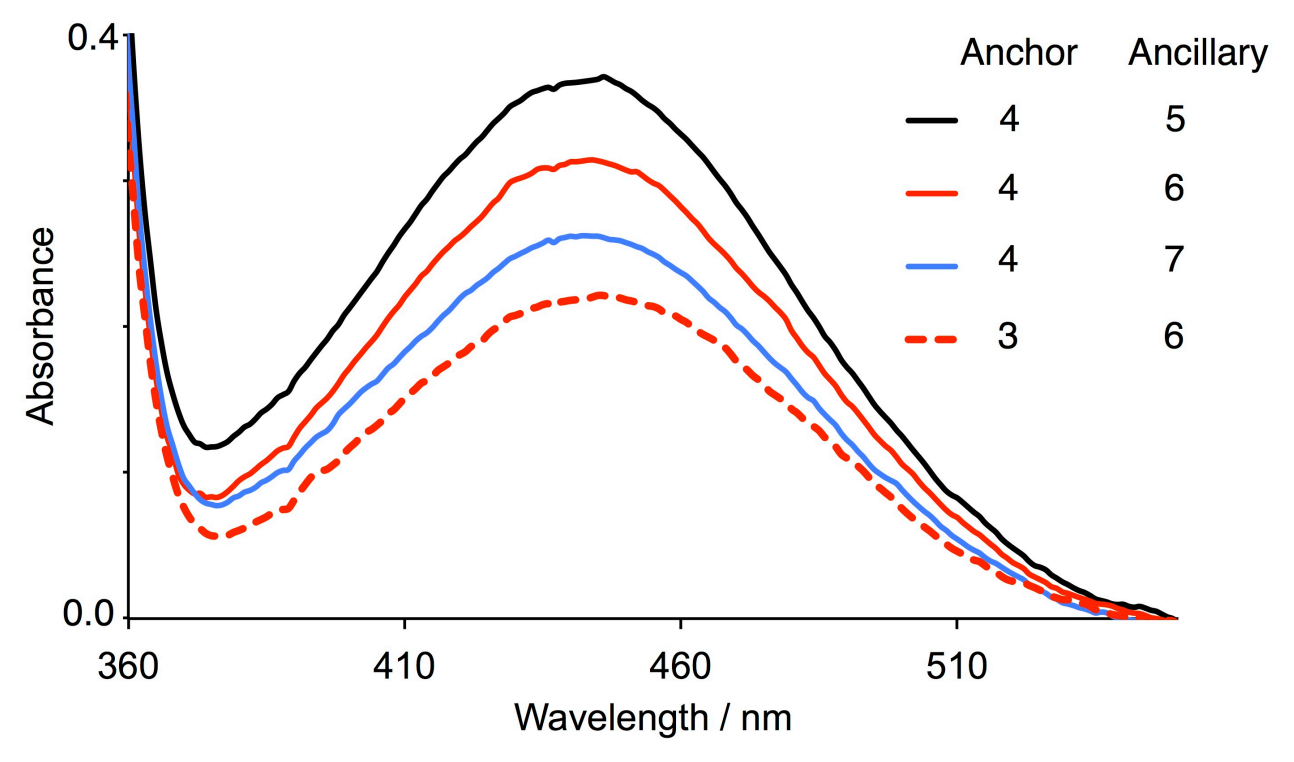

Figure 2. 


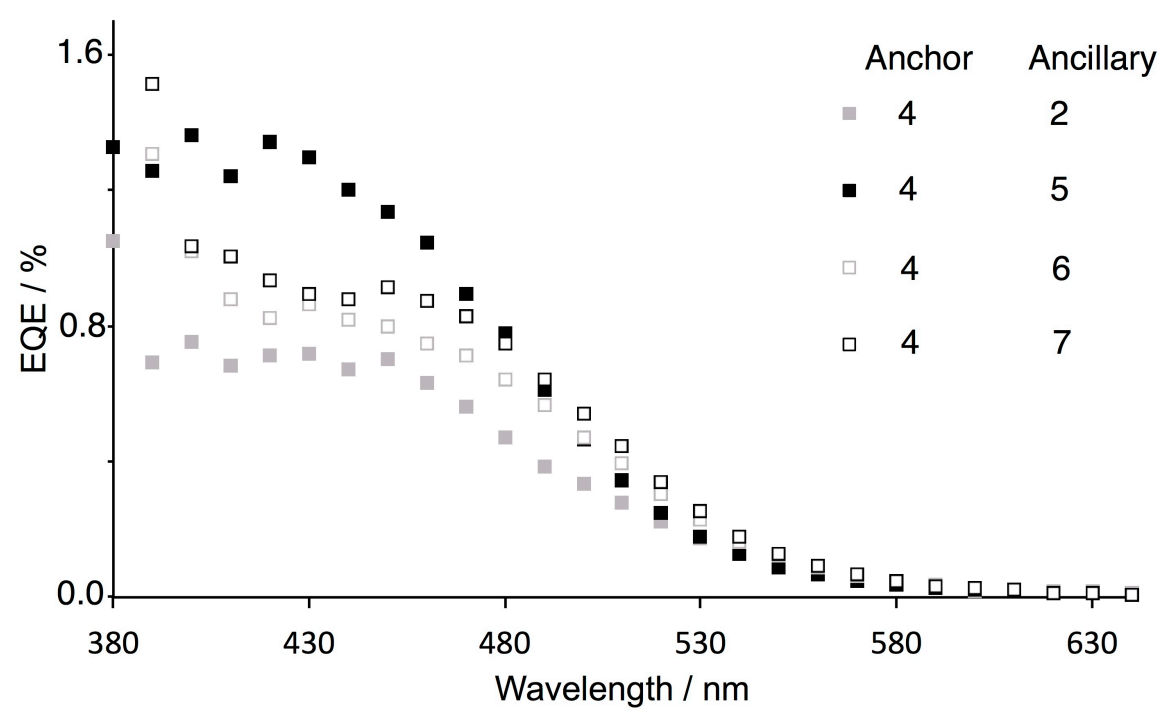

(a)

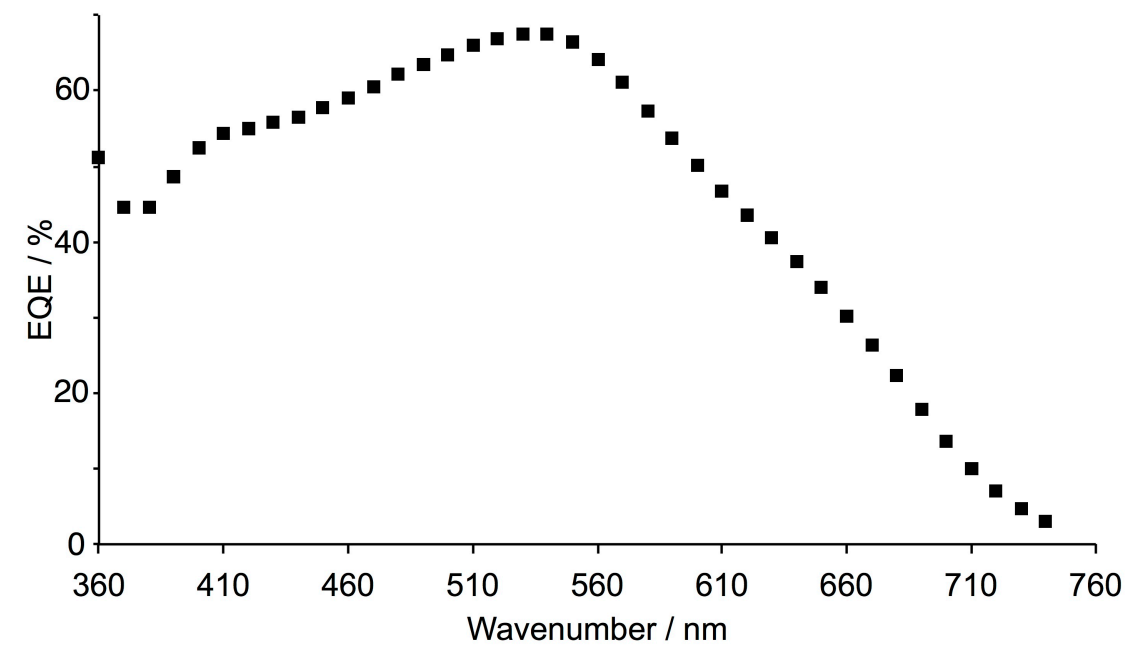

(b)

Figure 3. 
TABLES

Table 1 Solid state absorption maxima for electrodes functionalized with zinc(II) dyes.

\begin{tabular}{|l|l|}
\hline Dye & $\lambda_{\max } / \mathrm{nm}$ \\
\hline$[\mathrm{Zn}(\mathbf{3})(\mathbf{5})]^{2+}$ & 446 \\
\hline$[\mathrm{Zn}(\mathbf{3})(\mathbf{6})]^{2+}$ & 447 \\
\hline$[\mathrm{Zn}(\mathbf{3})(\mathbf{7})]^{2+}$ & 448 \\
\hline$[\mathrm{Zn}(\mathbf{4})(\mathbf{5})]^{2+}$ & 443 \\
\hline$[\mathrm{Zn}(\mathbf{4})(\mathbf{6})]^{2+}$ & 443 \\
\hline$[\mathrm{Zn}(\mathbf{4})(\mathbf{7})]^{2+}$ & 444 \\
\hline
\end{tabular}

Table 2. DSSC performance data for duplicate masked cells using the zinc(II) dyes with phosphonic acid anchoring ligand (4) compared to a DSSC containing N719 measured under the same conditions. Measurements were made on the day of fabricating the cells.

\begin{tabular}{|l|l|l|l|l|}
\hline Dye & $J_{\text {SC }} / \mathrm{mA} \mathrm{cm}^{-2}$ & $V_{\mathrm{OC}} / \mathrm{mV}$ & $\mathrm{ff} / \%$ & $\eta / \%$ \\
\hline$[\mathrm{Zn}(\mathbf{4})(\mathbf{2})]^{2+}$ & 0.21 & 379 & 64 & 0.05 \\
\hline$[\mathrm{Zn}(\mathbf{4})(\mathbf{2})]^{2+}$ & 0.20 & 377 & 55 & 0.04 \\
\hline$[\mathrm{Zn}(\mathbf{4})(\mathbf{5})]^{2+}$ & 0.51 & 440 & 63 & 0.14 \\
\hline$[\mathrm{Zn}(\mathbf{4})(\mathbf{5})]^{2+}$ & 0.72 & 467 & 67 & 0.23 \\
\hline$[\mathrm{Zn}(\mathbf{4})(\mathbf{6})]^{2+}$ & 0.45 & 428 & 66 & 0.13 \\
\hline$[\mathrm{Zn}(\mathbf{4})(\mathbf{6})]^{2+}$ & 0.45 & 421 & 64 & 0.12 \\
\hline$[\mathrm{Zn}(\mathbf{4})(\mathbf{7})]^{2+}$ & 0.41 & 436 & 65 & 0.12 \\
\hline$[\mathrm{Zn}(\mathbf{4})(\mathbf{7})]^{2+}$ & 0.36 & 411 & 63 & 0.09 \\
\hline $\mathrm{N} 719$ & 14.59 & 609 & 73 & 6.44 \\
\hline
\end{tabular}


Table 3. DSSC performance data for duplicate masked cells using the zinc(II) dyes with dicarboxylic acid anchoring ligand (3) compared to a DSSC containing N719 measured under the same conditions. Measurements were made on the day of fabricating the cells.

\begin{tabular}{|l|l|l|l|l|}
\hline Dye & $J_{\mathrm{SC}} / \mathrm{mA} \mathrm{cm}^{-2}$ & $V_{\mathrm{OC}} / \mathrm{mV}$ & $\mathrm{ff} / \%$ & $\eta / \%$ \\
\hline$[\mathrm{Zn}(\mathbf{3})(\mathbf{2})]^{2+}$ & 0.14 & 345 & 55 & 0.03 \\
\hline$[\mathrm{Zn}(\mathbf{3})(\mathbf{2})]^{2+}$ & 0.15 & 376 & 64 & 0.04 \\
\hline$[\mathrm{Zn}(\mathbf{3})(\mathbf{5})]^{2+}$ & 0.38 & 414 & 60 & 0.09 \\
\hline$[\mathrm{Zn}(\mathbf{3})(\mathbf{5})]^{2+}$ & 0.45 & 425 & 65 & 0.13 \\
\hline$[\mathrm{Zn}(\mathbf{3})(\mathbf{6})]^{2+}$ & 0.30 & 386 & 66 & 0.08 \\
\hline$[\mathrm{Zn}(\mathbf{3})(\mathbf{6})]^{2+}$ & 0.32 & 396 & 64 & 0.08 \\
\hline$[\mathrm{Zn}(\mathbf{3})(\mathbf{7})]^{2+}$ & 0.26 & 392 & 64 & 0.07 \\
\hline$[\mathrm{Zn}(\mathbf{3})(\mathbf{7})]^{2+}$ & 0.27 & 392 & 64 & 0.07 \\
\hline $\mathrm{N} 719$ & 14.59 & 609 & 73 & 6.44 \\
\hline
\end{tabular}


